\title{
Type of grinding of the main cereal of the diet affects production of brown egg-laying hens
}

\author{
A. Pérez-Bonilla ${ }^{\mathrm{a}}$, M. Frikha ${ }^{\mathrm{b}}$, R.P. Lázaro $^{\mathrm{b}}$, G.G. Mateos $^{\mathrm{b}, *}$ \\ a Camar Agroalimentaria S.L, Cedillo del Condado, Toledo 45214, Spain \\ b Departamento de Producción Animal, Universidad Politécnica de Madrid, 28040 Madrid, Spain
}

\section{A R T I C L E I N F O}

\section{Article history:}

Received 26 March 2014

Received in revised form 19 May 2014

Accepted 22 May 2014

\section{Keywords:}

Barley

Hammer mill

Laying hen performance

Maize

Roller mill

Wheat

\begin{abstract}
A B S T R A C T
The influence of method of grinding of the cereal of the diet on production and egg quality was studied in $420 \mathrm{Hy}$-line brown egg-laying hens. The design was completely randomized with six treatments arranged as a $3 \times 2$ factorial with three cereals (barley, dented maize and soft wheat) and two grinding procedures (hammer mill vs. roller mill). Each treatment was replicated seven times and the experimental unit was an enriched cage with ten hens. Production was recorded every four weeks from 24 to 59 weeks of age and egg quality was measured at 40 and 56 weeks of age. For the entire experiment, feed intake was higher in hens fed wheat or maize than in hens fed barley ( 110.8 and $110.7 \mathrm{vs.} 109.7 \mathrm{~g} / \mathrm{d} ; P=0.014$ ) but most of the differences were observed when the cereal was roller milled $(P=0.009$ for the interaction). Also, egg production was similar for the three diets when the cereal was hammer milled but tended to be lower for the barley than for the wheat or maize diets when the cereal was roller milled $(P=0.09$ for the interaction). None of the other productive or egg quality traits was affected by dietary treatment. We conclude that roller mills are useful to grind low fiber cereals, such as maize or wheat. However, the use of the roller mill might not be adequate when barley is the main cereal in diets for egg-laying hens.
\end{abstract}

(c) 2014 Elsevier B.V. All rights reserved.

\section{Introduction}

Maize (Zea mays L.) and soft wheat (Triticum aestivum L.) are the main cereals used in poultry diets worldwide, although barley (Hordeum vulgare L.) is also of common use (Gracia et al., 2003; Jacob and Pescatore, 2012). Maize is generally preferred to the other cereals because it has a more uniform nutritive value and provides a better structure of the feed, which might favour feed intake (FI) in poultry (Frikha et al., 2009a). Wheat and barley are less easily digested because of the presence of variable amounts of non-starch polysaccharides (NSP) (Lázaro et al., 2003; García et al., 2008; Mirzaie et al., 2012). Also, linoleic acid (LNL) content is higher in maize than in wheat or barley which favours its use in laying hen diets. However, Safaa et al. (2009) and Pérez-Bonilla et al. (2011) reported similar production and egg quality of brown egg-laying hens fed isonutritive diets based on maize, wheat or barley.

Abbreviations: AMEn, Nitrogen corrected apparent metabolizable energy; BW, body weight; DM, dry matter; FI, feed intake; FCR, feed conversion ratio; GMD, geometric mean diameter; GSD, geometric standard deviation; HM, hammer mill; LNL, linoleic acid; NDF, neutro detergent fiber; NSP, non-starch polysaccharides; RM, roller mill.

* Corresponding author. Tel.: +34 914524851; fax: +34 915499763.

E-mail address: gonzalo.gmateos@upm.es (G.G. Mateos). 
The interest on the effects of particle size of the diet on production of poultry has increased in recent years, as the industry continues to search for new practices to optimize feed efficiency (Frikha et al., 2009b; Safaa et al., 2009; Svihus, 2010b). Particle size affects the development of the gastrointestinal tract and voluntary FI in most avian species (Amerah et al., 2007; Jiménez-Moreno et al., 2010; Mateos et al., 2012). In fact, ISA Brown (2012) and Lohmann (2012) recommended that at least $75-80 \%$ of feed particles should be within the range of 500 and $3200 \mu \mathrm{m}$ to optimize FI and performance of laying hens. Two mills available to reduce the particle size of the grains in poultry diets are the hammer mill (HM) and the roller mill (RM). One of the main advantages of the RM as compared with the HM is the improvement in particle size uniformity which reduces dust generation and might benefit FI (Nir et al., 1990; Svihus et al., 2004). However, HM equipments are cheaper, easier to handle and have lower maintenance cost than RM equipments, which favours its use by the feed compound industry (Audet, 1995; Koch, 1996; Amerah et al., 2007). To the author knowledge, no information is available in the literature quantifying the potential interaction between cereal type and method of grinding of the cereal on production of brown egg-laying hens.

The hypothesis of this research was that barley, maize and wheat could be used indistinctly as the main cereal in diets for laying hens without any negative effect on performance or egg quality and that because of better feed uniformity, the use of a roller mill could improve hen performance as compared with the use of a hammer mill. The objectives of the study were to determine the influence of the main cereal of the diet (barley, maize or wheat) and grinding method (hammer mill vs. roller mill) and their potential interactions on production and egg quality of brown egg-laying hens from 24 to 59 weeks of age.

\section{Materials and methods}

\subsection{Husbandry, diets and experimental design}

All experimental procedures were approved by the animal Ethics Committee of the Universidad Politécnica de Madrid and were in compliance with the Spanish guidelines for the care and use of animals in research (Boletín Oficial del Estado, 2007).

In total, $420 \mathrm{Hy}$-Line Brown egg-laying hens were housed at 22 weeks of age in a totally environmental controlled barn and fed for two weeks a common pre-experimental diet based on maize and soybean meal that contained $11.5 \mathrm{MJ}, 175 \mathrm{~g}$ crude protein and $3.9 \mathrm{~g}$ digestible methionine per $\mathrm{kg}$. At 24 weeks of age, the hens were weighed individually ( $1733 \pm 48 \mathrm{~g}$ BW) and sorted at random in groups of 10 in 42 enriched cages ( $635 \mathrm{~mm} \times 1200 \mathrm{~mm}$; Facco S.A., Padova, Italy) provided with an open trough feeder and two nipple drinkers. Barn temperature was recorded daily throughout the experiment, with a minimum average value of $19 \pm 3{ }^{\circ} \mathrm{C}$ in January (start of the experiment) and a maximum of $25 \pm 3{ }^{\circ} \mathrm{C}$ in July (7th period of the experiment). The light program was constant throughout the experiment and consisted of $16 \mathrm{~h}$ of light per day.

Two batches per each of the three cereals were obtained from the same commercial sources and used during the experiment. The first batch was used for the first four experimental periods and the second batch for the last five periods. Each batch of cereal was divided in 2 portions and ground using either a HM (Model-DFZC, Bühler AG, Uzwil, Switzerland) or a double cylinder RM (Model-MDDP, Bühler AG, Uzwil, Switzerland). The HM had two screens and was driven by a $115 \mathrm{~kW}$ electric motor with a rotational speed of $1500 \mathrm{rpm}$. The diameter of the round holes of the screen was of $6.0 \mathrm{~mm}$ for maize and $5.0 \mathrm{~mm}$ for wheat and barley. The rolls of the RM had a diameter of $300 \mathrm{~mm}$ and a length of $1800 \mathrm{~mm}$. The distance between the grooves was of three and two $\mathrm{mm}$, for the upper and lower pair of rolls, respectively. The two rolls were driven by a $40 \mathrm{~kW}$ engine at a speed of $1040 \mathrm{rpm}$. The separation selected for the first pair of rolls was of $2.0 \mathrm{~mm}$ for wheat and barley and $1.0 \mathrm{~mm}$ for maize. For the second pair of rolls the distance chosen was $0.7 \mathrm{~mm}$ for wheat and maize and $0.6 \mathrm{~mm}$ for barley. The conditions during the feed manufacturing processes were controlled by specialized personnel (Catesa, Trujillo, Spain) and the objective was to achieve similar geometric mean diameter (GMD) for all the experimental feeds. After grinding, the cereal was mixed in adequate proportions with the other ingredients to manufacture the corresponding experimental diets.

All diets met or exceeded the nutrient requirements for brown egg-laying hens as recommended by Fundación Española Desarrollo Nutrición Animal, 2008. The ingredient composition of the feeds was adjusted to insure that all diets had similar AMEn and digestible indispensable amino acids (Lys, Met, Thr, Met + Cys and Trp) contents, according to Fundación Española Desarrollo Nutrición Animal, 2010. However, no attempt was made to equalize the LNL content of the diets that was $14.1 \mathrm{~g}, 11.1 \mathrm{~g}$ and $8.2 \mathrm{~g} / \mathrm{kg}$, for the maize, barley and wheat diets, respectively. All diets included a fixed amount of a commercial enzyme complex that included $\beta$-glucanase and xylanase activity (Endofeed, GNC Bioferm Inc., Saskatoon, SK, Canada) and a commercial pigment based on canthaxantin and the ester of $\beta$-apo-8-carotenoic (Miavit yellow/red, MIAVIT Nutrición Animal S.L., Tarragona, Spain). The ingredient composition and the calculated and determined nutritive value of the experimental diets are presented in Table 1.

The experiment was conducted as a completely randomized design with six diets organized in a factorial arrangement with two grinding methods (hammer vs. roller mill) and three main cereals (barley, maize and soft wheat). The experimental unit was a cage with ten birds for all traits studied.

\subsection{Laboratory analysis}

Representative samples of the diets were ground in a laboratory mill (Model Z-I, Retsch Stuttgart, Germany) provided with a 1-mm screen and analyzed for moisture by oven-drying (method 930.01), total ash using a muffle furnace (method 942.05) 
Table 1

Ingredient composition and chemical analyses of the experimental diets ( $\mathrm{g} / \mathrm{kg}$ as-fed basis, unless otherwise indicated).

\begin{tabular}{|c|c|c|c|c|c|c|}
\hline \multirow[b]{2}{*}{ Item } & \multicolumn{2}{|c|}{ Barley } & \multicolumn{2}{|c|}{ Maize } & \multicolumn{2}{|c|}{ Wheat } \\
\hline & Hammer mill & Roller mill & Hammer mill & Roller mill & Hammer mill & Roller mill \\
\hline \multicolumn{7}{|l|}{ Ingredient } \\
\hline Barley & 549.0 & 549.0 & - & - & 98.0 & 98.0 \\
\hline Maize & 51.0 & 51.0 & 549.0 & 549.0 & - & - \\
\hline Wheat & - & - & 51.0 & 51.0 & 549.0 & 549.0 \\
\hline Soybean meal (470 g CP/kg) & 245.0 & 245.0 & 269.0 & 269.0 & 225.0 & 225.0 \\
\hline Lard & 45.0 & 45.0 & 19.0 & 19.0 & 18.3 & 18.3 \\
\hline Dicalcium phosphate & 12.2 & 12.2 & 16.2 & 16.2 & 12.0 & 12.0 \\
\hline Limestone $^{\mathrm{a}}$ & 88.0 & 88.0 & 86.0 & 86.0 & 88.0 & 88.0 \\
\hline Sodium chloride & 3.0 & 3.0 & 3.0 & 3.0 & 3.0 & 3.0 \\
\hline DL-methionine (990 g/kg) & 1.8 & 1.8 & 1.8 & 1.8 & 1.7 & 1.7 \\
\hline Vitamin and mineral premix & 5.0 & 5.0 & 5.0 & 5.0 & 5.0 & 5.0 \\
\hline \multicolumn{7}{|l|}{ Calculated analysis ${ }^{c}$} \\
\hline AMEn (MJ/kg) & 11.5 & 11.5 & 11.5 & 11.5 & 11.5 & 11.5 \\
\hline Crude fiber & 37.0 & 37.0 & 25.0 & 25.0 & 29.2 & 29.2 \\
\hline Digestible Lys & 8.8 & 8.8 & 8.7 & 8.7 & 8.5 & 8.5 \\
\hline Digestible Met & 4.1 & 4.1 & 4.2 & 4.2 & 4.0 & 4.0 \\
\hline Digestible Met + Cys & 7.1 & 7.1 & 7.2 & 7.2 & 7.0 & 7.0 \\
\hline Digestible Thr & 6.1 & 6.1 & 6.1 & 6.1 & 6.1 & 6.1 \\
\hline Digestible Trp & 1.7 & 1.7 & 1.7 & 1.7 & 1.7 & 1.7 \\
\hline Calcium & 38.0 & 38.0 & 38.0 & 38.0 & 38.0 & 38.0 \\
\hline Total phosphorous & 7.0 & 7.0 & 7.0 & 7.0 & 7.0 & 7.0 \\
\hline Available phosphorous & 4.6 & 4.6 & 4.6 & 4.6 & 4.6 & 4.6 \\
\hline \multicolumn{7}{|l|}{ Determined analysis ${ }^{\mathrm{d}}$} \\
\hline Dry matter & 911 & 910 & 887 & 893 & 905 & 898 \\
\hline Gross energy (MJ/kg) & 15.35 & 15.37 & 15.37 & 15.36 & 15.36 & 15.37 \\
\hline Neutral detergent fiber & 125 & 127 & 73 & 73 & 98 & 98 \\
\hline Ether extract & 40.0 & 40.2 & 43.0 & 43.4 & 43.9 & 44.1 \\
\hline Crude protein & 173 & 169 & 173 & 174 & 171 & 172 \\
\hline Linoleic acid & 11.0 & 11.4 & 13.8 & 13.6 & 9.1 & 9.0 \\
\hline Ash & 127 & 130 & 120 & 128 & 127 & 128 \\
\hline
\end{tabular}

a $44.0 \mathrm{~g}$ of the calcium carbonate per kilogram of all diets was supplied coarsely ground (3-mm screen).

b Supplied the following (per kilogram of diet): vitamin A (trans-retinyl acetate), 10,000 IU; vitamin D3 (cholecalciferol), 2,000 IU; vitamin E (dl- $\alpha$ tocopheryl acetate), $10 \mathrm{mg}$; vitamin B1, $1 \mathrm{mg}$; vitamin B2, $4 \mathrm{mg}$; vitamin B6, $1 \mathrm{mg}$; vitamin B12 (cyanocobalamin), $15 \mu \mathrm{g}$; vitamin K3, $2.5 \mathrm{mg}$; choline (choline chloride), $150 \mathrm{mg}$; nicotinic acid, $25 \mathrm{mg}$; pantothenic acid (d-calcium pantothenate), $7.5 \mathrm{mg}$; folic acid, $0.10 \mathrm{mg} ; \mathrm{manganese}$ (MnO), $70 \mathrm{mg}$; zinc

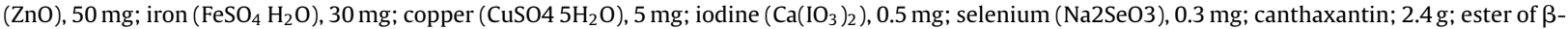
apo-8-carotenoic, $1.7 \mathrm{~g}$ (Lucanmix yellow/red, Basf, Tarragona, Spain), [Endo-1.3(4)- $\beta$-glucanase (EC 3.2.1.6), 150 IU/g]; [Endo-1.4- $\beta$-xylanase (EC 3.2.1.8), $105 \mathrm{IU} / \mathrm{g}$ (Endofeed, GNC Bioferm, Saskatchewan, SK, Canada)], Natuphos 5000 [300 FTU/kg of 6-phytase (EC 3.1.3.26), Basf Española, S.A., Tarragona, Spain].

c According to Fundación Española Desarrollo Nutrición Animal (2010).

d Chemical analyses were similar for the 2 batches of feed used ( 24 to 40 weeks and 40 to 59 weeks).

and nitrogen by combustion (method 990.03) using a LECO analyzer (Model FP-528, LECO, St. Joseph, MI) as described by AOAC International (2000). Neutral detergent fiber was determined sequentially as described by Van Soest et al. (1991), ether extract by Soxhlet analysis after $3 \mathrm{~N} \mathrm{HCl}$ acid hydrolysis (Boletín Oficial del Estado, 1995) and gross energy with an isoperibol bomb calorimeter (Model 356, Parr Instrument Company, Moline, IL). The LNL content of the diets was determined by gasliquid chromatography (GC-14B, Shimazy, Kyoto, Japan) as indicated by Grobas et al. (1999b). The particle size distribution and the GMD of the diets were determined in triplicate in $100 \mathrm{~g}$ samples using a Retsch shaker (Retsch, Stuttgart, Germany) provided with 8 sieves ranging in mesh from 5000 to $40 \mu \mathrm{m}$ according to the methodology outlined by ASAE (1995). The chemical composition and GMD of the two batches of diets used in this experiment were similar, and the average values are shown in Table 1.

\subsection{Production performance and egg quality}

Feed intake and egg production were recorded per replicate by period and for the entire experiment. Mortality was weighed and recorded as produced. Egg weight was measured in all eggs laid during the last three days of each of the nine four-week periods. From these data, egg production, egg weight, egg mass, average daily FI and feed conversion ratio (FCR) per $\mathrm{kg}$ and per dozen of eggs were calculated by period and cumulatively. In addition, all hens were weighed per replicate at the beginning and at the end of the experiment, and BW gain was determined per replicate.

The number of dirty, broken and shell-less eggs was recorded daily by replicate using all eggs produced. An egg was considered as dirty when a spot of any kind or size was detected on the shell as evaluated by two independent observers blind to treatment (Lázaro et al., 2003). Haugh units and yolk pigmentation were measured per replicate in twelve fresh eggs chosen at random from eggs produced the last two days ( $n=6$ per day) in two of the experimental periods ( 40 and 56 weeks of age). For this purpose, the Multitester equipment (QCM System, Technical Services and Supplies, Dunnington, York, 
Table 2

Particle size distribution ${ }^{\mathrm{a}}$ and geometric mean diameter of the experimental diets.

\begin{tabular}{|c|c|c|c|c|c|c|c|c|}
\hline \multirow[b]{2}{*}{ Cereal } & \multirow[b]{2}{*}{ Mill type } & \multicolumn{5}{|c|}{ Sieve diameter $(\mu \mathrm{m})$} & \multirow[b]{2}{*}{80} & \multirow[t]{2}{*}{$\mathrm{GMD}^{\mathrm{b}} \pm \mathrm{GSD}^{\mathrm{c}}(\mu \mathrm{m})$} \\
\hline & & 2,500 & 1,250 & 630 & 315 & 160 & & \\
\hline \multirow[t]{2}{*}{ Barley } & Hammer & 12.9 & 32.3 & 33.3 & 17.8 & 3.6 & 0.1 & $1,117 \pm 2.03$ \\
\hline & Roller & 7.6 & 40.8 & 33.2 & 14.5 & 3.9 & - & $1,116 \pm 1.92$ \\
\hline \multirow[t]{2}{*}{ Maize } & Hammer & 13.9 & 33.6 & 34.1 & 14.4 & 3.6 & 0.4 & $1,162 \pm 2.13$ \\
\hline & Roller & 6.6 & 35.9 & 28.9 & 19.2 & 9.2 & 0.2 & $955 \pm 2.02$ \\
\hline \multirow[t]{2}{*}{ Wheat } & Hammer & 12.8 & 36.0 & 30.8 & 16.0 & 4.2 & 0.2 & $1,141 \pm 2.05$ \\
\hline & Roller & 4.0 & 42.5 & 31.9 & 14.9 & 6.6 & 0.1 & $1,033 \pm 1.96$ \\
\hline
\end{tabular}

a Analyzed in triplicate according to ASAE (1995). The proportion of particles smaller than $80 \mu \mathrm{m}$ and bigger than $2500 \mu \mathrm{m}$ was negligible for all diets.

b Geometric mean diameter. Data correspond to the average of the diets supplied from 24 to 40 weeks and from 40 to 59 weeks of age.

c Geometric standard deviation. (Log normal SD).

UK) was used (Pérez-Bonilla et al., 2011). In addition, the proportion of shell, albumen and yolk, and the yolk to albumen ratio were determined per replicate in the eggs used for quality measurements as indicated by Pérez-Bonilla et al. (2012). Briefly, fresh raw eggs were broken and the yolk was carefully separated from the albumen. The yolk was rolled on paper tissue to remove any adhered albumen and the chalazae prior to weighing. The shell was carefully washed, dried at room temperature for $48 \mathrm{~h}$ and weighed. Albumen weight was calculated by difference between egg weight and the weights of the yolk and the shell.

\subsection{Statistical analysis}

Production data and egg quality traits were analyzed as a completely randomized design using the MIXED procedure of SAS for repeated measures with the main cereal and grinding method as fixed effects, and period (four weeks for production and sixteen weeks for egg quality traits) as the repeated term (Littell et al., 1996). Several covariance structures were tested and the final structure was selected according to the Akaike' information criterion. Results in tables are presented as means, and differences were considered significant at $P<0.05$. Mortality data were analyzed by the GENMOD procedure of SAS Institute (1990) using a binomial distribution. The link function was logit-transformation $[\ln (\mu / 1-\mu)]$. Values are represented in biological sense using logit function as transformation.

\section{Results}

\subsection{Particle size distribution and geometric mean diameter}

The GMD of the diets ranged from $955 \mu \mathrm{m}$ for the RM maize to $1141 \mu \mathrm{m}$ for the HM wheat (Table 2). As compared with the HM, rolling reduced the GMD of the maize (1162 vs. $955 \mu \mathrm{m})$ and wheat $(1141 \mathrm{vs.} 1033 \mu \mathrm{m})$ diets but did not affect that of the barley diets (1117 vs. $1116 \mu \mathrm{m}$ ). The geometric standard deviation (GSD) of the diets was lower when the cereal was RM than when the cereal was HM (1.96 vs. $2.07 \mu \mathrm{m}$, respectively). The proportion of feed particles that passed through the $160 \mu \mathrm{m}$ screen was increased when the RM rather than the HM was used to grind the maize (4.0 vs. 9.4\%) and the wheat (4.4 vs. 6.7\%) but no differences were observed for the barley (3.7 vs. 3.9\%) (Table 2). On the other hand, the proportion of feed particles coarser than $2500 \mu \mathrm{m}$ was reduced when the cereal was roller milled (a 59, 47 and 31\% reduction for the barley, maize and wheat diets, respectively) (Table 2).

\subsection{Production performance}

The main cereal of the diet did not affect egg weight (62.3,62.2 and 61.9 g), egg mass (55.6, 56.3 and $56.0 \mathrm{~g} / \mathrm{d}$ ), FCR per kg $(1.98,1.97$ and 1.98$)$ or per dozen $(1.47,1.47$ and 1.48) of eggs, BW gain $(232,247$ and $223 \mathrm{~g})$ or hen mortality $(1.1,3.3$ and $0.6 \%$ ) (Table 3). On the other hand, the method used to grind the cereal did not affect egg weight (62.2 vs. $62.1 \mathrm{~g}$ ), egg mass ( 56.3 vs. $55.6 \mathrm{~g} / \mathrm{d}$ ), FCR per kg (1.97 vs. 1.98 ) or per dozen of eggs (1.47 vs. 1.48$)$, BW gain (238 vs. $230 \mathrm{~g}$ ) or mortality (2.2 vs. $1.1 \%$ ). However, an interaction between grinding method and main cereal of the diet was detected for FI and egg production; hens fed the RM barley diet consumed 2.2\% less feed than hens fed the HM barley diet (110.9 vs. $108.4 \mathrm{~g} / \mathrm{d}$ ) but no differences were detected for hens fed the maize or the wheat diets ( $P=0.009$ for the interaction) (Table 3$)$. Consequently, cumulative FI was higher $(P=0.004)$ in hens fed the HM cereals than in hens fed the RM cereals ( $110.9 \mathrm{vs.} 109.9 \mathrm{~g}$, respectively) with most of the difference observed during the second part of the laying cycle (Fig. 1). Also, cumulative FI was higher $(P=0.014)$ in hens fed maize or wheat than in hens fed barley (110.7 and $110.8 \mathrm{vs.} 109.7 \mathrm{~g} / \mathrm{d}$, respectively) (Table 3) with most of the differences detected in the second part of the laying cycle (Fig. 2). Hens fed the RM barley diet tended to produce less eggs than hens fed the HM barley diet (0.906 vs. 0.879 eggs/hen per day) but no differences between mill types were detected for hens fed the maize or wheat diets ( $P=0.09$ for the interaction). 
Table 3

Influence of the main cereal and type of mill used to grind the cereal on productive performance from 24 to 59 weeks of age ${ }^{a}$.

\begin{tabular}{|c|c|c|c|c|c|c|c|c|c|}
\hline Cereal & Mill type & $\begin{array}{l}\text { Egg } \\
\text { production }^{\mathrm{b}}\end{array}$ & $\begin{array}{l}\text { Feed } \\
\text { intake } \\
(\mathrm{g} / \mathrm{d})\end{array}$ & $\begin{array}{l}\text { Egg } \\
\text { weight (g) }\end{array}$ & Egg mass $^{c}$ & $\begin{array}{l}\mathrm{FCR}^{\mathrm{d}} \\
(\mathrm{kg} / \mathrm{kg})\end{array}$ & $\begin{array}{l}\text { FCR } \\
\text { (kg/dozen } \\
\text { eggs) }\end{array}$ & $\begin{array}{l}\text { BW gain } \\
\text { (g) }\end{array}$ & $\begin{array}{l}\text { Mortality } \\
(\%)\end{array}$ \\
\hline \multirow[t]{2}{*}{ Barley } & Hammer & 0.906 & $110.9^{a}$ & 62.4 & 56.5 & 1.96 & 1.46 & 238 & 2.2 \\
\hline & Roller & 0.879 & $108.4^{b}$ & 62.2 & 54.7 & 1.99 & 1.48 & 226 & 0.0 \\
\hline \multirow[t]{2}{*}{ Maize } & Hammer & 0.903 & $110.8^{a}$ & 62.2 & 56.2 & 1.98 & 1.47 & 241 & 4.4 \\
\hline & Roller & 0.905 & $110.6^{a}$ & 62.3 & 56.3 & 1.97 & 1.48 & 254 & 2.2 \\
\hline \multirow[t]{2}{*}{ Wheat } & Hammer & 0.906 & $110.9^{\mathrm{a}}$ & 62.0 & 56.2 & 1.98 & 1.47 & 236 & 0.0 \\
\hline & Roller & 0.904 & $110.6^{a}$ & 61.8 & 55.9 & 1.98 & 1.48 & 209 & 1.1 \\
\hline S.E.M ${ }^{\mathrm{f}}$ & & 0.007 & 0.40 & 0.23 & 0.51 & 0.020 & 0.015 & 22.7 & \\
\hline \multicolumn{10}{|l|}{ Cereal } \\
\hline Barley & & 0.893 & $109.7^{b}$ & 62.3 & 55.6 & 1.98 & 1.47 & 232 & 1.1 \\
\hline Maize & & 0.904 & $110.7^{\mathrm{a}}$ & 62.2 & 56.3 & 1.97 & 1.47 & 247 & 3.3 \\
\hline Wheat & & 0.905 & $110.8^{a}$ & 61.9 & 56.0 & 1.98 & 1.48 & 223 & 0.6 \\
\hline S.E.M ${ }^{g}$ & & 0.005 & 0.28 & 0.16 & 0.36 & 0.014 & 0.011 & 16.1 & \\
\hline \multicolumn{10}{|l|}{ Mill type } \\
\hline Hammer & & 0.905 & $110.9^{a}$ & 62.2 & 56.3 & 1.97 & 1.47 & 238 & 2.2 \\
\hline Roller & & 0.896 & $109.9^{b}$ & 62.1 & 55.6 & 1.98 & 1.48 & 230 & 1.1 \\
\hline S.E.M ${ }^{\mathrm{h}}$ & & 0.004 & 0.23 & 0.13 & 0.29 & 0.011 & 0.009 & 13.1 & \\
\hline \multicolumn{10}{|l|}{ Effect } \\
\hline Cereal & & 0.14 & 0.014 & 0.23 & 0.45 & 0.89 & 0.98 & 0.55 & 0.10 \\
\hline Grinding & & 0.11 & 0.004 & 0.57 & 0.12 & 0.71 & 0.19 & 0.64 & 0.31 \\
\hline Cereal*mill type & & 0.09 & 0.009 & 0.80 & 0.14 & 0.73 & 0.96 & 0.69 & 0.36 \\
\hline
\end{tabular}

(a-b) Means within a column and main effects not sharing a common superscript are different $(P<0.05)$.

a Data presented correspond to the means of 8 periods of 28 days each.

b Eggs/hen per day.

c Grams of eggs/hen per day

d FCR = feed conversion ratio.

e Analyzed by GENMOD procedure.

f Standard error of the mean: ( $n=7$ replicates of 10 hens).

g Standard error of the mean: ( $n=14$ replicates of 10 hens).

h Standard error of the mean: ( $n=21$ replicates of 10 hens).
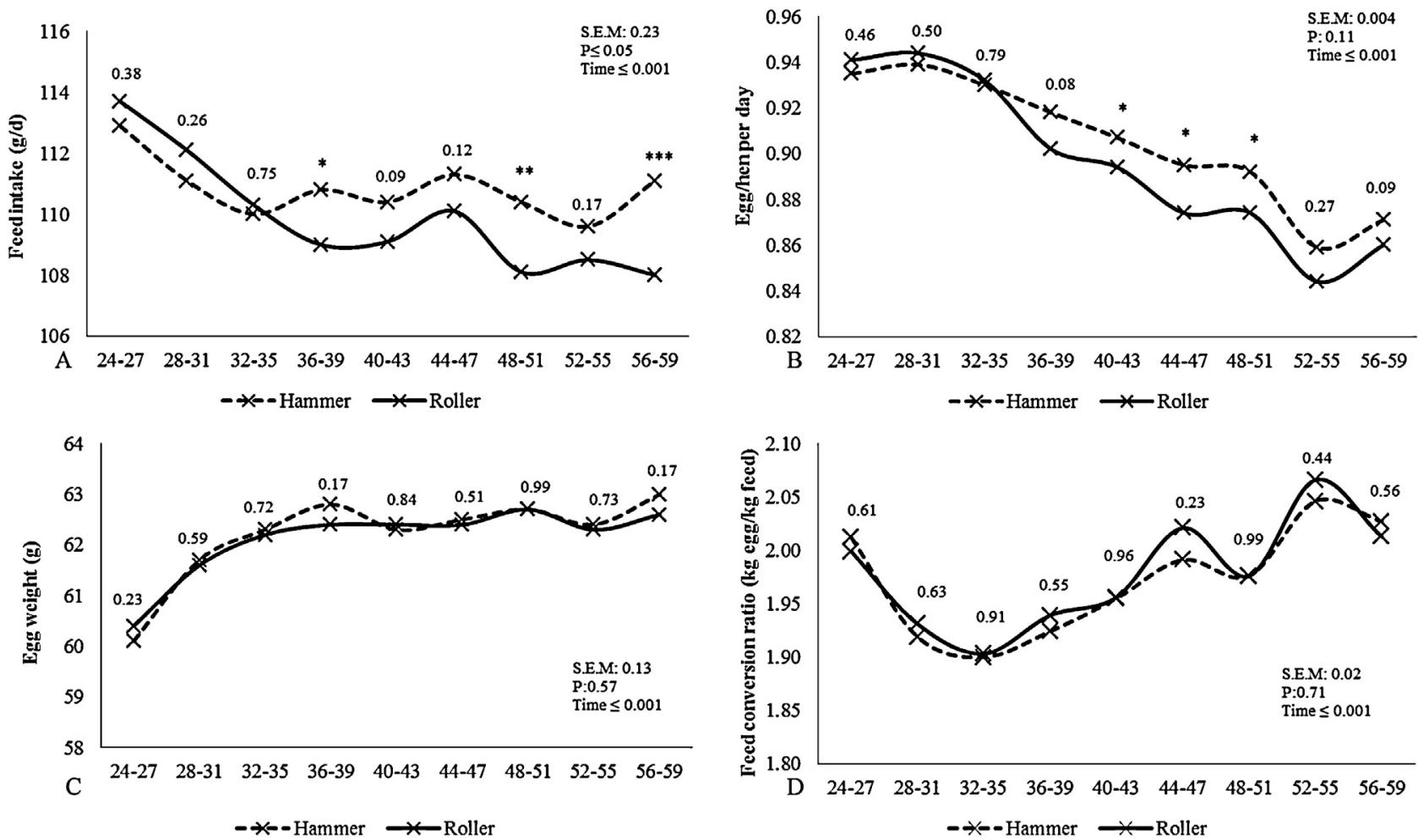

Fig. 1. Effect of grinding method of the cereal on feed intake (A), egg production (B), egg weight (C) and feed conversion ratio (D) from 24 to 59 weeks of age.

${ }^{*} P \leq 0.05 ;{ }^{* *} P \leq 0.01 ;{ }^{* *} P \leq 0.001$. The $\mathrm{y}$-axis value does not start in the origin. 

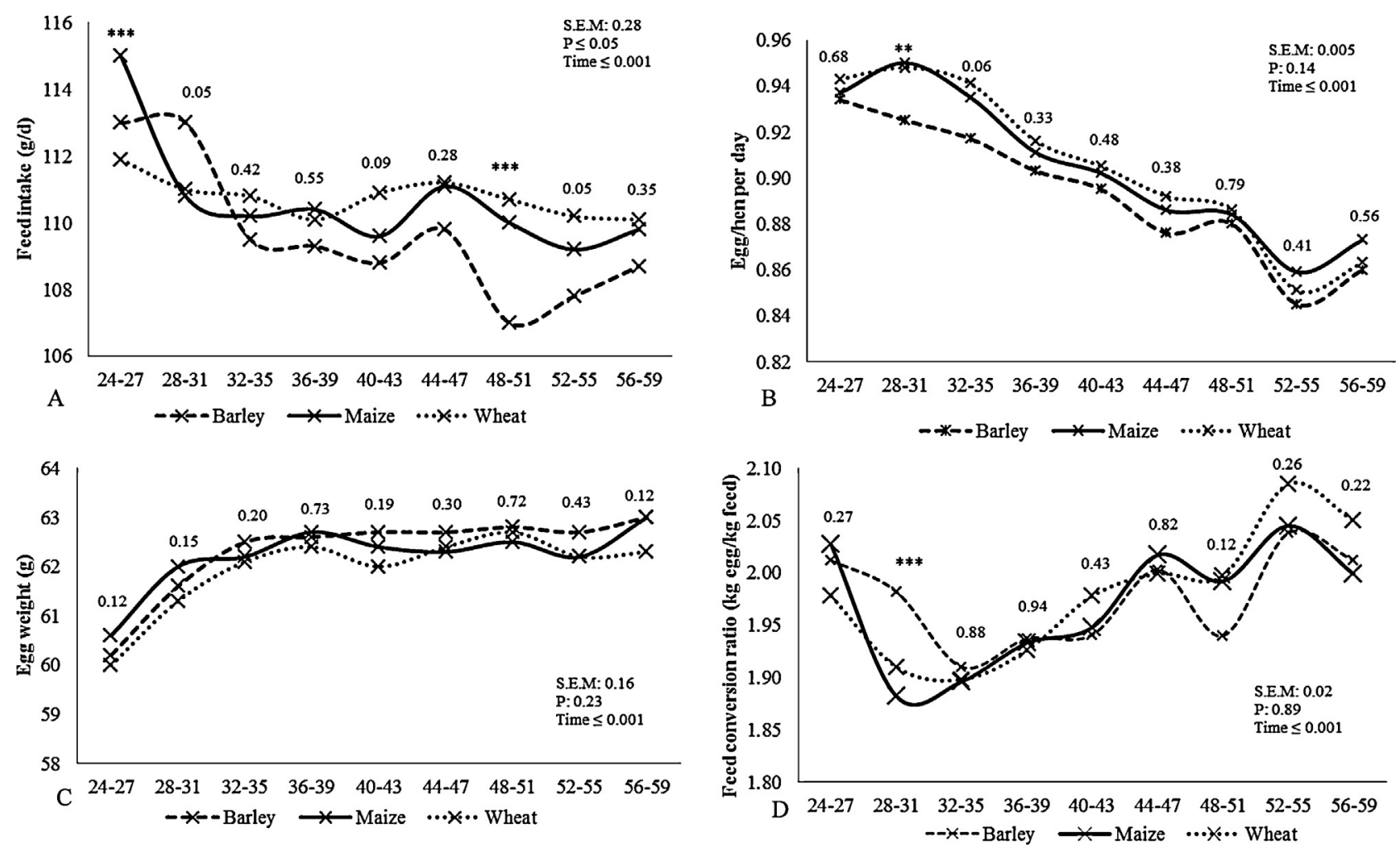

Fig. 2. Effect of the main cereal of the diet on feed intake (A), egg production (B), egg weight (C) and feed conversion ratio (D) from 24 to 59 weeks of age. ${ }^{* *} P \leq 0.01 ;{ }^{* * *} P \leq 0.001$. The $y$-axis value does not start in the origin.

\subsection{Egg quality}

No interactions between cereal and grinding method of the cereal were detected for any of the egg quality traits studied and therefore, only main effects are presented. Percentage of dirty, broken and shell-less eggs, Haugh units and the proportion of shell, yolk, albumen, and the yolk to albumen ratio, were not affected by dietary treatment (Table 4). However, yolk colour was higher $(P<0.001)$ in hens fed maize than in hens fed barley or the wheat ( 9.6 vs. 8.8 and 8.8 , respectively).

\section{Discussion}

\subsection{Particle size distribution and geometric mean diameter}

The GMD of the barley diet was not affected by type of mill used but that of the maize and wheat diet were lower with the RM than with the HM, reflecting probably differences in NDF content among cereals. Irrespective of the cereal used, the GSD of the diets was reduced when the RM was used, results that agree with data of Koch (1996) who indicated that particle size uniformity of the diet was higher with the RM than with the HM. The proportion of particles finer than $160 \mu \mathrm{m}$ of the maize and wheat diets was higher with the HM than with the RM, but no differences were observed for the barley diet. The authors have not found any published research on the effects of method of grinding of the three cereals on particle size distribution and GSD of the diets. Nir et al. (1990) compared diets for broilers from 1 to $14 \mathrm{~d}$ of age based on sorghum that was ground fine, medium or coarse, using a HM or a RM. The screen size of the HM used was 2-, 4- or $8 \mathrm{~mm}$ and the gap between rollers of the RM was $0.45-, 0.65-$ and $1.0 \mathrm{~mm}$. The authors reported 6\% lower GMD for the RM than for the HM diets, in agreement with the results of the current study for corn and wheat. Douglas et al. (1990) ground maize and sorghum using a HM provided with a $4.8 \mathrm{~mm}$ or a RM with $0.625 \mathrm{~mm}$ gap between rolls and reported lower GSD. Thus, the uniformity was higher with the RM than with HM for both cereals, in agreement with the results of the current research. The data from all these researches using different cereals ground with a HM or with a RM must be taken with caution because often the effects of milling type and GMD of the diets are confounded.

In the current experiment, the GMD of the HM diets was similar for wheat and maize. In contrast, Safaa et al. (2009) using a HM provided with a 6-, 8- or 10-mm screen reported that the GMD was 22, 17 and $7 \%$ higher for the wheat than for the maize diets. In the experiment of Safaa et al. (2009) a Triticum durum (hard wheat) variety was used whereas a Triticum aestivum (soft wheat) variety was used in the current experiment. In this respect, Gutiérrez-Álamo (2008) reported that hard 
Table 4

Influence of the main cereal and type of mill used to grind the cereal on egg quality variables ${ }^{\mathrm{a}}$.

\begin{tabular}{|c|c|c|c|c|c|c|c|c|c|c|}
\hline \multirow[t]{2}{*}{ Cereal } & \multirow[t]{2}{*}{ Mill type } & \multirow[t]{2}{*}{$\begin{array}{l}\text { Dirty } \\
\text { eggs (\%) }\end{array}$} & \multirow[t]{2}{*}{$\begin{array}{l}\text { Broken } \\
\text { eggs (\%) }\end{array}$} & \multirow[t]{2}{*}{$\begin{array}{l}\text { Shell-less } \\
\text { eggs (\%) }\end{array}$} & \multirow[t]{2}{*}{$\begin{array}{l}\text { Haugh } \\
\text { units }\end{array}$} & \multirow[t]{2}{*}{$\begin{array}{l}\text { Yolk } \\
\text { colour }^{\mathrm{b}}\end{array}$} & \multicolumn{3}{|c|}{$\begin{array}{l}\text { Weight of egg components (\% } \\
\text { of the egg) }\end{array}$} & \multirow[t]{2}{*}{$\begin{array}{l}\text { Yolk to } \\
\text { albumen ratio }\end{array}$} \\
\hline & & & & & & & Shell & Yolk & Albumen & \\
\hline \multirow[t]{2}{*}{ Barley } & Hammer & 6.7 & 1.4 & 0.03 & 84.7 & 8.9 & 10.2 & 24.6 & 65.1 & 0.38 \\
\hline & Roller & 5.2 & 1.4 & 0.13 & 85.1 & 8.6 & 10.2 & 24.3 & 65.5 & 0.37 \\
\hline \multirow[t]{2}{*}{ Maize } & Hammer & 6.5 & 1.3 & 0.06 & 84.4 & 9.8 & 10.2 & 24.5 & 65.3 & 0.38 \\
\hline & Roller & 6.7 & 0.9 & 0.07 & 85.0 & 9.4 & 10.3 & 24.8 & 65.0 & 0.38 \\
\hline \multirow[t]{2}{*}{ Wheat } & Hammer & 5.6 & 1.2 & 0.07 & 85.0 & 8.9 & 10.3 & 24.8 & 64.9 & 0.38 \\
\hline & Roller & 6.9 & 1.7 & 0.09 & 84.3 & 8.7 & 10.0 & 24.7 & 65.3 & 0.38 \\
\hline S.E.M ${ }^{\mathrm{c}}$ & & 0.64 & 0.28 & 0.038 & 1.85 & 0.29 & 0.11 & 0.30 & 0.39 & 0.008 \\
\hline \multicolumn{11}{|l|}{ Cereal } \\
\hline Barley & & 6.0 & 1.4 & 0.08 & 84.9 & $8.8^{\mathrm{b}}$ & 10.1 & 24.5 & 65.3 & 0.38 \\
\hline Maize & & 6.6 & 1.1 & 0.07 & 84.7 & $9.6^{\mathrm{a}}$ & 10.2 & 24.6 & 65.2 & 0.38 \\
\hline Wheat & & 6.3 & 1.4 & 0.08 & 84.8 & $8.8^{\mathrm{b}}$ & 10.1 & 24.7 & 65.3 & 0.38 \\
\hline S.E.M ${ }^{\mathrm{d}}$ & & 0.45 & 0.20 & 0.030 & 1.35 & 0.20 & 0.08 & 0.21 & 0.28 & 0.006 \\
\hline \multicolumn{11}{|l|}{ Mill type } \\
\hline Hammer & & 6.3 & 1.3 & 0.06 & 84.7 & 9.2 & 10.2 & 24.6 & 65.1 & 0.38 \\
\hline Roller & & 6.3 & 1.3 & 0.09 & 84.8 & 8.9 & 10.2 & 24.6 & 65.2 & 0.38 \\
\hline S.E.M ${ }^{\mathrm{e}}$ & & 0.37 & 0.16 & 0.022 & 0.10 & 0.15 & 0.07 & 0.18 & 0.23 & 0.005 \\
\hline \multicolumn{11}{|l|}{ Effect } \\
\hline Cereal & & 0.62 & 0.46 & 0.87 & 0.94 & 0.001 & 0.52 & 0.94 & 0.96 & 0.57 \\
\hline Grinding & & 0.99 & 0.90 & 0.15 & 0.45 & 0.12 & 0.73 & 0.97 & 0.89 & 0.29 \\
\hline $\begin{array}{l}\text { Cereal*mill } \\
\text { type }\end{array}$ & & 0.11 & 0.32 & 0.25 & 0.82 & 0.86 & 0.68 & 0.57 & 0.57 & 0.99 \\
\hline
\end{tabular}

(a-b) Means within a column and main effects not sharing a common superscript are different $(P<0.05)$.

a Dirty, broken and shell-less eggs data correspond to the mean of 8 periods of 28 days each. Haugh units, yolk colour, weight components of the egg and yolk to albumen ratio data correspond to the average value of the measurements of 10 eggs chosen at random at 40 and 56 weeks of age.

b Measured using the DSM colour fan.

c Standard error of the mean: ( $n=7$ replicates of 10 hens).

d Standard error of the mean: ( $n=14$ replicates of 10 hens).

e Standard error of the mean: ( $n=21$ replicates of 10 hens).

and soft wheat have different physico-chemical characteristics, with a higher proportion of cleaved starch granules for the hard than for the soft wheat, which might affect the final structure and particle size of the cereal.

\subsection{Production performance}

\subsubsection{Cereal}

When the grains were hammer milled, egg production, egg weight and FCR were not affected by the main cereal of the diet, consistent with data of Pérez-Bonilla et al. (2011) and Lázaro et al. (2003) comparing diets based on the three cereals. In contrast, Coon et al. (1988) reported higher FI, lower egg size and reduced feed efficiency and BW gain in hens fed a barley diet than in hens fed a maize diet but in this research, the feeds were not supplemented with enzymes. Wheat and barley are often produced in non-irrigated fields, which results in a more variable nutritive value than maize which is produced in irrigated lands. In broilers, Cowieson et al. (2010) reported that the response to enzyme supplementation was higher when fed diets based on low quality wheat than when fed diets based on high quality wheat. Consequently, depending on the physico-chemical characteristics of the grains, poultry might respond differently to diets based on barley, maize or wheat. Moreover, the potential differences in nutritive value among cereals might disappear, when the diets are supplemented with an adequate combination of enzymes (Gracia et al., 2003; Mirzaie et al., 2012).

Egg weight was not affected by the main cereal of the diet in spite of differences in LNL content (average of 9.1, 11.2 and $13.7 \mathrm{~g} \mathrm{LNL} / \mathrm{kg}$ diet for the wheat, barley and maize diets, respectively). The NRC (1994) recommends a minimum intake of $11.0 \mathrm{~g} \mathrm{LNL} / \mathrm{kg}$ diet, a value that was higher than that of the wheat diets. Scragg et al. (1987) reported that brown egg-laying hens needed more than $20 \mathrm{~g} \mathrm{LNL} / \mathrm{kg}$ diet to maximize egg size. In fact, some commercial guidelines for management and nutrition of laying hens (ISA Brown, 2012; Lohmann, 2012) recommend a minimum of $18.0 \mathrm{~g}$ LNL/kg diet to optimize egg production and insure a rapid increase in egg size at the beginning of the laying period. Consequently, a lower egg weight should be expected in hens fed wheat than in hens fed maize. The information provided herein, however, does not support the use of levels of LNL in the diet over $11.0 \mathrm{~g} / \mathrm{kg}$ to maximize egg size, consistent with the researches of Jensen et al. (1958), Shutze et al. (1959) and Grobas et al. (1999a). In this respect, Safaa et al. (2008) demonstrated that an increase in the LNL content of the diet from $11.2 \mathrm{~g} / \mathrm{kg}$ to $16.0 \mathrm{~g} / \mathrm{kg}$ did not affect egg weight in brown egg-laying hens from 59 to 70 weeks of age. The data reported herein support the findings of Grobas et al., 1999b,c and Pérez-Bonilla et al. (2011) indicating that hens respond with an increase in egg size to increases in LNL of the diet but only until a certain level is reached (around $1.0-1.2 \mathrm{~g} / \mathrm{kg}$ diet $)$. Once this level is reached, fat content of the diet, rather than LNL content, might be responsible for further increases in egg size. 


\subsubsection{Milling of the cereal}

The information available on the effects of grinding method of the cereal on production of laying hens is very scarce. Deaton et al. (1989) compared in three experiments the influence of grinding method (HM and RM) of maize on performance of white hens. The screen size of the HM was of $4.8 \mathrm{~mm}$ and the gap between rolls of the RM was $0.635 \mathrm{~mm}$. The grinding method did not affect any of the performance variables studied in any of the three experiments, consistent with the results reported herein for the corn diet. In the research of Deaton et al. (1989) the GMD of the diets was higher with the RM than with the HM (ranging from 1343 to $1501 \mu \mathrm{m}$ and from 814 to $873 \mu \mathrm{m}$ across the three experiments, respectively). Consequently, the effects of grinding method and particle size of the diet were confounded and therefore, no conclusion on the effects of mill type on hen performance can be reached.

In the current research, hens fed diets based on RM cereals ate less feed than hens fed diets based on HM cereals but most of the difference detected was caused by the lower FI detected in hens fed the RM barley diets. In fact, no differences in FI were observed when the cereals were HM. Also, hens fed the RM barley diets tended to produce less eggs than hens fed the RM maize or wheat diets, a finding that was consistent with the reduction in Fl observed. Nir et al. (1990) compared in young broilers diets based on fine, medium or coarse ground sorghum using either a HM provided with a 2-, 4 and $8 \mathrm{~mm}$ screen (GMD of the diets ranging from $629 \mu \mathrm{m}$ to $829 \mu \mathrm{m}$ ) or a RM with a gap between rollers of 0.45-, 0.65 and $1.0 \mathrm{~mm}$ (GMD of the diets ranging from $558 \mu \mathrm{m}$ to $748 \mu \mathrm{m}$ ). The authors failed to detect any significant effect of mill type on bird performance but FI and BW gain increased as the particle size of the diet increased. In laying hens, Safaa et al. (2009) compared maize and durum wheat ground with a HM provided with a 6-, 8- or 10-mm screen and reported also a significant increase in FI, as the particle size of the diet increased. However, egg production, egg mass and FCR were not affected by the GMD of the diet, in agreement with the results of the current research.

Feed intake of the hens was reduced when fed the RM barley diet as compared when fed the HM barley. However, no differences were detected in hens fed the maize or wheat diets. The reason for the decrease in FI observed in hens fed the RM barley diet is not known but might be related, at least in part, with changes in the physical characteristics of the cereals, including particle size distribution. The proportion of particles that passed through the $1,250 \mu \mathrm{m}$ screen was $11.0 \%$ and $4.7 \%$ lower with the HM than with the RM for the maize and wheat diets, respectively but $7.0 \%$ higher for the RM barley diet than for the HM barley diet. Hetland et al. (2002) and Svihus (2010a) reported that coarse particles remain for longer in the gizzard than fine particles. Consequently, the higher proportion of coarse particles of the RM barley diet will accumulate in the gizzard, resulting in satiation and in a decrease in FI (González-Alvarado et al., 2007, 2008; Jiménez-Moreno et al., 2009). In addition, the NDF fraction of the cereal, which is higher for the barley than for the wheat and maize diets, concentrates in the coarser portion of the feed. Moreover, the NDF of barley has a high content in insoluble NSP, a fraction with a high capacity to retain large amounts of water (Bach Knudsen, 1997). Mateos et al. (2012) suggested that the combination of high proportion of coarse particles and high insoluble NSP content of barley might accentuate the retention of the digesta in the gizzard and reduce voluntary FI. Also, the structure of the diets based on RM barley, as per direct observation, was poorer and less uniform than that of the other diets, which might have penalized voluntary FI of the hens. The data reported herein indicate that hens respond differently to cereal inclusion in the diet depending on the mill used, a finding that has to be taken into account in feed manufacturing. It seems, however, that the ability of the gizzard of laying hens to grind low fiber cereals, such as maize and wheat, is high and that under most practical conditions, a reduction in particle size of these two cereals will not affect hen performance.

\subsection{Egg quality}

Type of cereal did not affect any of the egg quality traits studied except for egg yolk colour that was increased when maize was used. The information available on the effects of the main cereal of the diet on egg quality traits is scarce. Mirzaie et al. (2012) reported similar albumen and shell quality in white hens fed diets based on wheat or maize. Lázaro et al. (2003) indicated in white hens, that the main cereal of the diet (barley, maize and wheat) did not affect any of the quality traits studied (shell weight, percentage of shell-less, and Haugh units). Lázaro et al. (2003) reported also similar incidence of dirty eggs in hens fed barley than in hens fed wheat or maize but when the diets were supplemented with enzymes. The beneficial effect of maize feeding on yolk colour was expected because all diets, independent of the cereal used, were supplemented with the same amount of an exogenous pigment source.

As expected, type of mill did not affect any of the quality traits of the eggs studied. The authors have not found any report on the effects of grinding method on egg quality traits except that of Deaton et al. (1989) who reported that egg shell breaking strength of the eggs was not affected by the type of mill used.

\section{Conclusions}

Grinding the cereal with a roller mill improved particle size uniformity as compared with the use of the hammer mill. An interaction between main cereal of the diet and grinding method on voluntary FI and egg production was detected; hens fed the barley based diet had lower FI and tended to produce less eggs than hens fed the wheat or maize based diets when the cereals were roller milled but no differences were detected when the cereals were hammer milled. It is concluded that roller mills can be used to process low fiber cereals such as maize and wheat but its use to grind barley, might not be recommended. 


\section{Conflicts of interest}

\section{The authors confirm that there are not conflicts of interest in this research}

\section{References}

Amerah, A.M., Ravindran, V., Lentle, R.G., Thomas, D.G., 2007. Feed particle size: implications on the digestion and performance of poultry. World Poult. Sci. J. 63, 439-451.

AOAC International, 2000. Association of Official Analysis Chemists. Official Method of Analysis of the Association of Official Analytical Chemists International. 17th ed. AOAC, Gaithersburg, MD, USA.

ASAE, 1995. American Society of Agriculture Engineers. Method of Determining and Expressing Fineness of Feed Material by Sieving. ASAE standard S319.2. In: Agriculture Engineers Yearbook of Standard. ASAE, St Joseph, MO, pp. 461-462.

Audet, L., 1995. Emerging feed mill technology: keeping competitive. Anim. Feed Sci. Technol. 53, 157-170.

Bach Knudsen, K.E., 1997. Carbohydrate and lignin content of plant materials used in animal feeding. Anim. Feed Sci. Technol. 67, 319-338.

Boletín Oficial del Estado, 1995. Real Decreto 2257/1994 por el que se aprueba los métodos oficiales de análisis de piensos o alimentos para animales y sus primeras materias. BOE 52, 7161-7237.

Boletín Oficial del Estado. 2007. Ley 32/2007 de 7 de Noviembre para el cuidado de los animales, en su explotación, transporte, experimentación y sacrificio. BOE 268, 45914-45920.

Coon, C.N., Obi, I., Hamre, M.L., 1988. Use of barley in laying hen diets. Poult. Sci. 67, 1306-1313.

Cowieson, A.J., Bedford, M.R., Ravindran, V., 2010. Interactions between xylanase and glucanase in maize-soy-based diets for broilers. Brit. Poult. Sci. 51, $246-257$.

Deaton, J.W., Lott, B.D., Simmons, J.D., 1989. Hammer mill versus roller mill grinding of corn for commercial egg layers. Poult. Sci. 68, 1342-1344.

Douglas, J.H., Sullivan, T.W., Bond, P.L., Struwe, F.J., Baier, J.G., Robeson, L.G., 1990. Influence of grinding, rolling, and pelleting on the nutritional value of grain sorghums and yellow corn for broilers. Poult. Sci. 69, 2150-2156.

Frikha, M., Safaa, H.M., Serrano, M.P., Arbe, X., Mateos, G.G., 2009a. Influence of the main cereal and feed form of the diet on performance and digestive tract of brown-egg laying pullets. Poult. Sci. 88, 994-1002.

Frikha, M., Safaa, H.M., Jiménez-Moreno., E., Lázaro, R., Serrano, M., Mateos, G.G., 2009b. Influence of energy concentration and feed form of the diet on growth performance and digestive traits of brown egg-laying pullets from 1 to 120 days of age. Anim. Feed Sci. Technol. 153, 292-302.

Fundación Española Desarrollo Nutrición Animal, 2008. Necesidades Nutricionales para Avicultura: Pollos de Carne y Aves de Puesta. In: Lázaro, R., Mateos, G.G. (Eds). FEDNA, Madrid, Spain.

Fundación Española Desarrollo Nutrición Animal, 2010. Normas FEDNA para la Formulación de Piensos Compuestos. In: De Blas, C., Mateos, G.G., Rebollar, P.G. (Eds). FEDNA, Madrid, Spain.

García, M., Lázaro, R., Latorre, M.A., Gracia, M.I., Mateos, G.G., 2008. Influence of enzyme supplementation and heat processing of barley on digestive traits and productive performance of broilers. Poult. Sci. 87, 940-948.

González-Alvarado, J.M., Jiménez-Moreno, E., Lázaro, R., Mateos, G.G., 2007. Effects of cereal, heat processing, and fiber on productive performance and digestive traits of broilers. Poult. Sci. 86, 1705-1715

González-Alvarado, J.M., Jiménez-Moreno, E., Valencia, D.G., Lázaro, R., Mateos, G.G., 2008. Effects of fiber source and heat processing of the cereal on the development and $\mathrm{pH}$ of the gastrointestinal tract of broilers fed diets based on corn or rice. Poult. Sci. 87, 1779-1795.

Gracia, M.I., Latorre, M.A., García, M., Lázaro, R., Mateos, G.G., 2003. Heat processing of barley and enzyme supplementation of diets for broilers. Poult. Sci. $82,1281-1291$.

Grobas, S., Mateos, G.G., Mendez, J., 1999a. Influence of dietary linoleic acid on productive and egg weight of eggs and egg components in young brown hens. J. Appl. Poult. Res. 8, 177-184.

Grobas, S., Mendez, J., De Blas, C., Mateos, G.G., 1999b. Influence of dietary energy, supplemental fat and linoleic acid concentration on performance of laying hens at two ages. Brit. Poult. Sci. 40, 681-687.

Grobas, S., Mendez, J., De Blas, C., Mateos, G.G., 1999c. Laying hen productivity as affected by energy, supplemental fat, and linoleic acid concentration of the diet. Poult. Sci. 78, 1542-1551.

Gutiérrez-Álamo, A., 2008. Variability in wheat: factors affecting its nutritional value. World Poult. Sci. J. 64, 20-39.

Hetland, H., Svihus, B., Olaisen, V., 2002. Effect of feeding whole cereals on performance, starch digestibility and duodenal particle size distribution in broiler chickens. Brit. Poult. Sci. 43, 416-423.

ISA Brown, 2012. Nutrition Management Guide. Institut de Selection Animale. B.V. Boxmeer, The Netherlands.

Jacob, J.P., Pescatore, A.J., 2012. Using barley in poultry diets - A review. J. Appl. Poult. Res. 21, 915-940.

Jensen, L.S. Allred, J.B., Fry, R.E., McGinnis, J., 1958. Evidence for an unidentified factor necessary for maximum egg weight in chickens. J. Nutr. 65, 219-233.

Jiménez-Moreno, E., González-Alvarado, J.M., De Coca-Sinova, A., Lázaro, R., Mateos, G.G., 2009. Effects of source of fibre on the development and pH of the gastrointestinal tract of broilers. Anim. Feed Sci. Technol. 154, 93-101.

Jiménez-Moreno, E., González-Alvarado, J.M., González-Sánchez, D., Lázaro, R., Mateos, G.G., 2010. Effects of type and particle size of dietary fiber on growth performance and digestive traits of broilers from 1 to 21 days of age. Poult. Sci. 89, 2197-2212.

Koch, K., 1996. Hammermills and Rollermills. MF-2048 Feed Manufacturing. Dept. Grain Sci. Ind. Kansas State University, Manhattan, KS.

Lázaro, R., García, M., Araníbar, M.J., Mateos, G.G., 2003. Effect of enzyme addition to wheat, barley and rye-based diets on nutrient digestibility and performance of laying hens. Brit. Poult. Sci. 44, 256-265.

Littell, R.C., Milliken, G.A., Stroup, W.W., Wolfinger, R.D., 1996. SAS System for Mixed Models. SAS Institute Inc., Cary, NC.

Lohmann, 2012. Management Guide for Laying Hens: Lohmann Brown-Classic. Lohmann Tierzuch GmbH, Cuxhaven, Germany.

Mateos, G.G., Jiménez-Moreno, E., Serrano, M.P., Lázaro, R., 2012. Poultry response to high levels of dietary fiber sources varying in physical and chemical characteristics. J. Appl. Poult. Res. 21, 156-174.

Mirzaie, S., Zaghari, M., Aminzadeh, M., Shivazad, M., Mateos, G.G., 2012. Effects of wheat inclusion and xylanase supplementation of the diet on productive performance, nutrient retention, and endogenous intestinal enzyme activity of laying hens. Poult. Sci. 91, 413-425.

Nir, I., Melcion, J.P., Picard, M., 1990. Effect of particle size of sorghum grains on feed intake and performance of young broilers. Poult. Sci. 69, 2177-2184

NRC, 1994. Nutrient Requirements of Poultry. 9th rev. ed. Natl. Acad. Press, Washington, DC.

Pérez-Bonilla, A., Frikha, M., Mirzaie, S., García, J., Mateos, G.G., 2011. Effects of the main cereal and type of fat of the diet on productive performance and egg quality of brown-egg laying hens from 22 to 54 weeks of age. Poult. Sci. 90, 2801-2810.

Pérez-Bonilla, A., Novoa, S., García, J., Mohiti-Asli, M., Frikha, M., Mateos, G.G., 2012. Effect of energy concentration of the diet on productive performance and egg quality of brown egg-laying hens differing in initial body weight. Poult. Sci. 91, 3156-3166.

Safaa, H.M., Serrano, M.P., Valencia, D.G., Arbe, X., Jiménez-Moreno, E., Lázaro, R., Mateos, G.G., 2008. Effects of the levels of methionine, linoleic acid, and added fat in the diet of productive performance and egg quality of brown laying hens in the late phase of production. Poult. Sci. 87, 1595-1602.

Safaa, H.M., Jiménez-Moreno, E., Valencia, D.G., Frikha, M., Serrano, M.P., Mateos, G.G., 2009. Effect of main cereal of the diet and particle size of the cereal on productive performance and egg quality of brown egg-laying hens in early phase of production. Poult. Sci. 88, 608-614

SAS Institute., 1990. SAS STAT User's Guide: Version 6, 4th ed. SAS Inst. Inc., Cary, NC.

Scragg, R.H., Logan, N.B., Geddes, N., 1987. Response of egg weight to the inclusion of various fats in layer diets. Brit. Poult. Sci. 28, 15-21.

Shutze, J.V., Jensen, L.S., McGinnis, J., 1959. Further studies on unidentified nutritional factors affecting egg size. Poult. Sci. 38, 1247-1252 
Svihus, B., Klovstad, K.H., Pérez, V., Zimonja, O., Sahlstrom, S., Schüller, R.B., Jeksrud Prestlokken, E., 2004. Physical and nutritional effects of pelleting of broiler chicken diets made from wheat ground to different coarsenesses by the use of roller mill and hammer mill. Anim. Feed Sci. Technol. 117, 281-293.

Svihus, B., 2010a. The gizzard: function, influence of diet structure and effects on nutrient availability. World Poult. Sci. J. 67, 207-224

Svihus, B., 2010b. Challenging current poultry feeding dogmas by feed intake restriction and the use of coarse feed ingredients. 21 st. Proc. of the Austr. Poult. Sci. Symp., 9-16, Sydney Australia.

Van Soest, P., Robertson, J.J., Lewis, A., 1991. Methods for dietary fiber, neutral detergent fiber, and nonstarch polyssacharides in relation to animal nutrition. J. Dairy Sci. 74, 3583-3597. 